\title{
JEZSUITA TUDÓSOK DIGITALIZÁLT KÉZIRATGYÚJTEMÉNYEI AZ ELTE EGYETEMI KÖNYVTÁRBAN ÉS LEHETSÉGES KUTATÁSI TÉMÁIK
}

\author{
MÁTYÁs MELINDA \\ ELTE Egyetemi Könyvtár Gyűjteményszervezési Osztály, könyvtáros
}

\begin{abstract}
ABSZTRAK'T
Az ELTE Egyetemi Könyvtár igen értékes forrásgyújteménye a három jezsuita tudós, Hevenesi Gábor, Kaprinai István és Pray György nevéhez kötődő kéziratos kollekció. A 17-18. századból származó összeállítás eredeti okleveleket és másolatokat is tartalmaz, számos darabja a magyar történelem és művelődéstörténet szempontjából egyedi forrásértékkel bír. A kéziratgyüjtemény a 18. század végén és a 19. század elején került az Egyetemi Könyvtárba. A kollekció az állományvédelem és a jobb kutathatóság érdekében digitalizálásra került, s a tételeinek leírásai megtalálhatóak az Egyetemi Könyvtár nyilvános katalógusában. Tanulmányomban szólok a gyűjtemény általános jellemzőiről, a digitalizálásáról és utómunkálatairól, valamint bemutatom, hogyan érhetô el a kollekció az OPAC-ban és az EDIT - az ELTE Digitális Intézményi Tudástár - felületén. A továbbiakban pedig példaként röviden ismertetek néhány kutatási területet, amelyhez hasznos forrásul szolgálhat a gyűjtemény. Ennek keretében lesz szó Kanizsai Dorottya történelmi alakjáról és a mohácsi csata előtti és utáni időkről.
\end{abstract}

\section{Bevezetés}

Az ELTE Egyetemi Könyvtár Kézirat- és Ritkaságtárának egyik legértékesebb része a mintegy tizenöt folyóméternyi ${ }^{1}$ Hevenesi-, Kaprinai-, Pray-kéziratgyűjtemény. Ezek közül Pray kollekciója 1784-ben került a Könyvtárba, a másik kettő pedig 1790 tavaszán Pray György közremúködésével. ${ }^{2}$ A kollekció értékes pl. latin, német, magyar nyelvű dokumentumokat, leveleket, történelmi forrásokat tartalmaz, amelyek a múvelődéstörténet, történelemkutatás szempontjából felbecsülhetetlen jelentőséggel bírnak. ${ }^{3}$

A következőkben bemutatom a kéziratos anyagot általánosan, majd a digitalizálásáról és az integrált könyvtári rendszerben való feldolgozásáról lesz szó, és végül felvillantok néhány kutatási területet, amelyben hasznos lehet a gyűjteményt forrásként használni.

\section{A kollekció névadói}

Ahhoz, hogy közelebb kerüljünk a gyüjteményhez, érdemes megismernünk névadóikat és a szándékaikat, amelyek a gyüjtésre vezérelték őket. A legkorábban Hevenesi Gábor (1656-1715) jezsuita egyháztörténész, tanár, kartográfus ${ }^{4}$ kezdte az iratok másolását és másoltatását bollandista példákat követve. ${ }^{5}$ 1692-ben megjelent Régi magyar szentség c. múvének elsô kiadása ${ }^{6}$, amelyben elsôként írt a Magyarországon élt szentekrôl. Ennek anyaggyűjtése során tűnt fel neki a szűkös forrásanyag, s feltámadt benne a magyar- 


\section{MÁTYÁs MELINDA}

országi egyháztörténeti és történeti források szisztematikus feldolgozásának igénye. Részben ennek hatására írta meg a Modus materiae... címú felhívását, amely buzdítás és módszertani útmutató az egyháztörténeti források gyűjtésére és gyűjtéséhez. ${ }^{7}$ Hevenesi életében eredetileg 133 kötetnyi forrás gyűlt össze. ${ }^{8}$

Hevenesi Gábort követte közvetlenül Kaprinai István (1714-1785) jezsuita tanár és történész, ${ }^{9}$ a jezsuita történetíró iskola első nemzedékének tagja. ${ }^{10}$ Érdemei közé tartozik, hogy rendezte Hevenesi Gábor kéziratgyüjteményét, ${ }^{11}$ valamint az egyháztörténeten kívül egyéb történeti forrásokat is másolt: állami levéltárak anyagait (például Pozsonyban és Kassán), emellett bejutott a leleszi konvent levéltárába is, továbbá neves fơuri családok archívumaiból is végzett gyüjtéseket. ${ }^{12}$ Összesen 102 saját kötete gyűlt össze a másolatokból. A kollekció értékét mutatja az is, hogy Kaprinai halála után a pozsonyi Magyar Kamara lefoglaltatta azt előzetes tanulmányozás céljából, s csak negyvenegy középkori oklevelet adott át oktatási célra az Egyetemi Könyvtárnak. ${ }^{13}$

A harmadik névadó Pray György (1723-1800) jezsuita történész, aki részben Hevenesi adatgyújtő iskoláját követi, de már a kritikai irányzat képviselője. ${ }^{14}$ Fontos tevékenysége volt, hogy átvizsgálta a kamarai levéltárt tudományos céllal. ${ }^{15}$ Nevéhez füződik a Halotti beszédet tartalmazó kódex felfedezése, amely a Pray-kódex nevet kapta. Az egyetemhez több szállal is kapcsolódik: II. József megbízásából oklevéltant, majd címerés pecséttant tanított a bölcsészkar elődjében 1782-től ${ }^{16}$ körülbelül 1784-ig (a későbbi tanrendekben már nem szerepel); emellett 1777-1780 között, valamint 1784-1790-ig az Egyetemi Könyvtár társ-főigazgatója volt. ${ }^{17}$ 1784-ben megkötötték a szerződést József királlyal arra, hogy életjáradék fejében átadja a gyújteményét, de a tényleges és visszamenőleges kifizetésre csak 1787-ben került sor. ${ }^{18}$

\section{A gyüjtemény digitalizálása, feldolgozása és elérése az. EDIT intézményi repozitóriumban}

A kéziratos kollekció digitalizálására 2010-2011 között került sor az Arcanum Kft. jóvoltából. ${ }^{19}$ Összesen 128000 képfájl terjedelmű lett a digitalizált változat, amelynek feldolgozása és az EDIT intézményi repozitóriumban publikálása 2013-2014-ben történt meg az NKA támogatásával. Az Aleph integrált könyvtári rendszerben feldolgozáshoz segítségül használtuk a Dedek Crescens Lajos-féle igen részletes katalógust. ${ }^{20}$ Dedek Crescens Lajos jegyzékének felosztását követtük az egyes levelek, történelmi dokumentumok megkülönböztetésében, tehát ami a Dedek-katalógusban egy tétel, az megfelel az elektronikus katalógus egy tételének. Az EDIT repozitóriumba való feltöltéshez néhány kéziratot újra kellett szkennelni a jobb láthatóságért, valamint jelenleg is folyik a könyvtári rendszerben a kéziratos dokumentumok leírásának ellenőrzése, javítása, szükség esetén az eredeti kézirat alapján. A repozitóriumos megjelenítésnél az volt a cél, hogy az elektronikus katalógusban szereplő részletes leírás is látszódjon a kép mellett, így meg kellett feleltetni az integrált könyvtári rendszer MARC21 formátumú leírásait a tudástárban használt Dublin Core (DC) adatcsere-formátummal. Ehhez a MARC21-leírás minden szükséges mezőjéhez és almezőjéhez ki lett választva a DC megfelelő adateleme, majd a konvertálás a múvelet elindítása után automatikusan hajtódott végre. ${ }^{21}$ Jelenleg a http://edit.elte.hu 
oldalon a Muzeális gyűjtemények, E-könyvtár menüpontot, majd a Hevenesi Kaprinai Pray linket választva lehet elérni a tudástárból a teljes digitalizált kollekciót. A gyújteményt kiválasztva lehetőségünk van böngészésre és keresésre is azon belül.

A különgyújtemény számos kéz által történt másolatokból tevődik össze, ezért az írás minőségétől, jellemzőjétől függően hol nehezebb, hol könnyebb kiolvasni a szöveget. Az értelmezéshez segítségül nagy felbontású képek lettek feltöltve, amelyekbe kellő mértékben bele lehet nagyítani a jobb olvashatóságért. ${ }^{22}$

Az EDIT repozitórium mellett nézzük meg, hogyan néz ki egy feldolgozott tétel az integrált könyvtári rendszerben! A következő képeken ugyanannak a rekordnak az Aleph-es leírása (1. ábra) és az EDIT-es metaadatai („A tétel részletes adatai”) (2. ábra) láthatók.

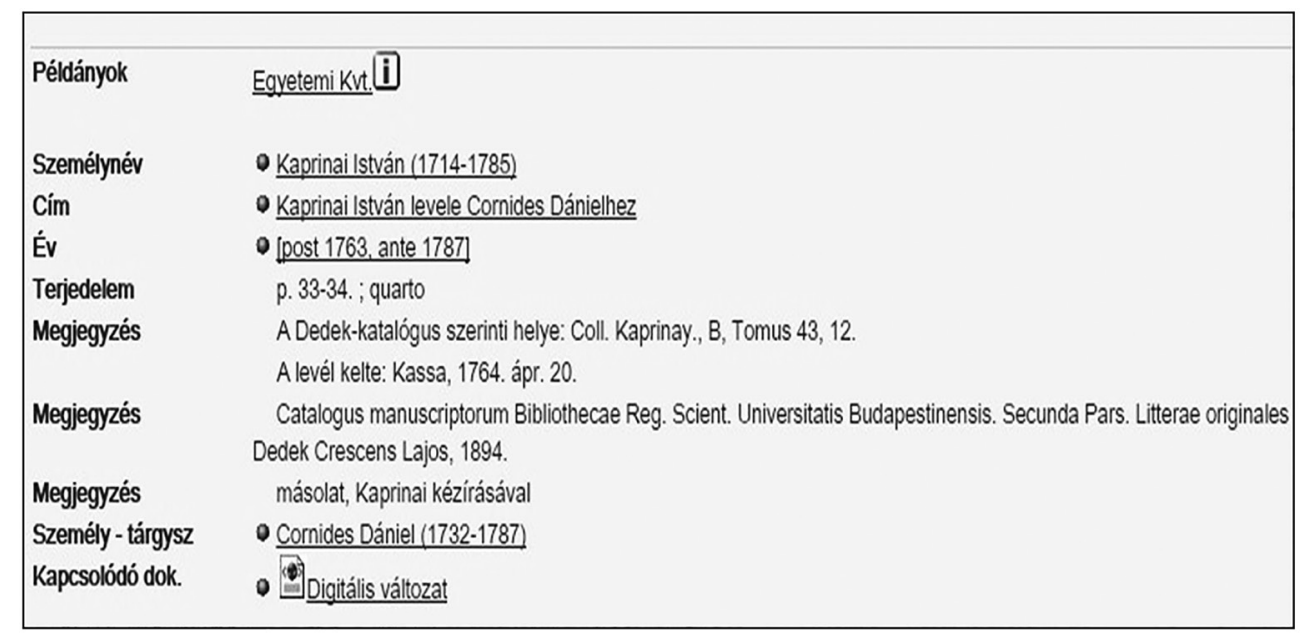

1. ábra: Aleph-rekord

Az Aleph-ben a Cím mezőben látható a Dedek-katalógus leírása és egyes rekordoknál a kézirat „címe” is, ha a kettő különbözik. A Személynév mezőben, ha ismert a szerző, ő szerepel (pl. egy levélnél az író), a címzett pedig a Személynév - tárgyszó rovatban. Az évnél áll a másolat keletkezésének feltételezett időintervalluma, a terjedelemnél a kézirat oldalszámozása szerinti lapszámok, a megjegyzésekben pedig minden esetben a Dedek-katalógus hivatkozása, valamint az adott dokumentumra vonatkozó megjegyzések (ha van, a pontos keltezés, fizikai tulajdonságok, pl. kézírás, lapszéli jegyzetek). Az EDIT-ből kiemeltem azokat az adatelemeket, amelyek a katalógus leírásában ezeket a részeket lefedik. Mivel a DC-formátum egyszerúbb, mint a MARC21, a Személynév - tárgyszó a Kulcsszó mezőben szerepel, s nincsenek különböző fajtájú megjegyzések, mint a MARC21-ben. A repozitórium és a könyvári katalógus kapcsolatát a „Rekord azonosító” elem biztosítja, a rövid leírásban a linkre kattintva könnyen átnavigálhatunk a katalógusra. 
MÁTYÁs MELINDA

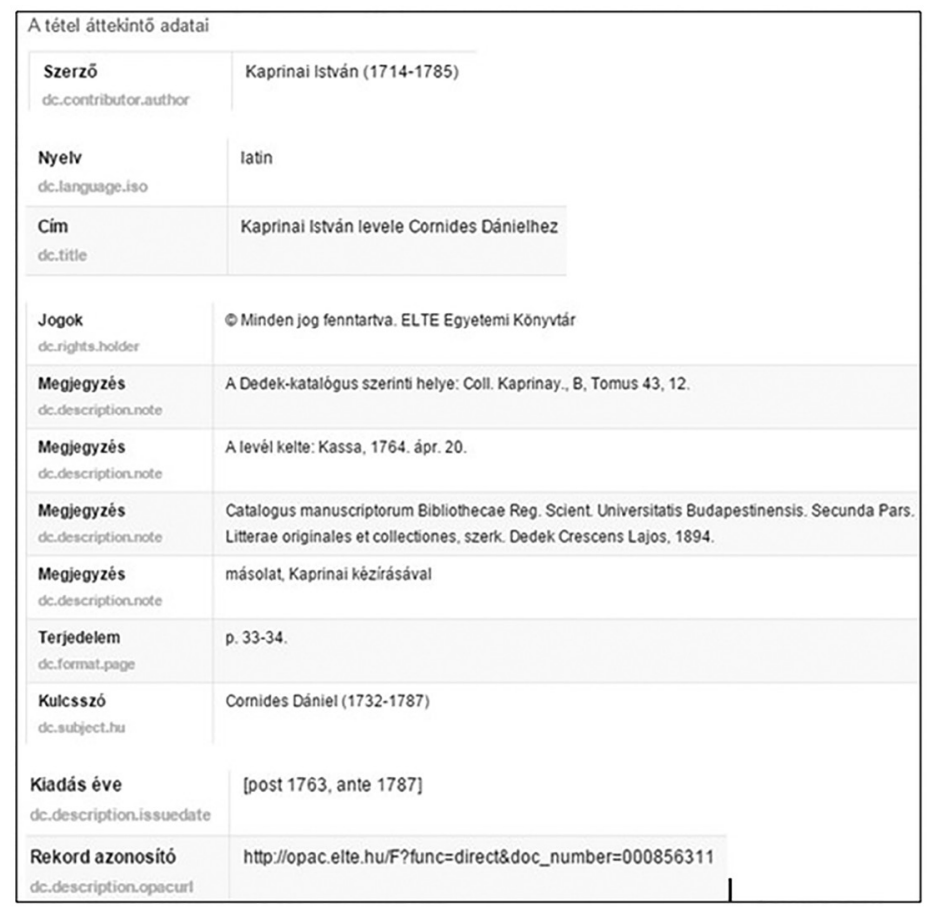

2. ábra: EDIT-rekord

\section{A gyüjtemény mint forrás kutatása}

Az eddig feldolgozott és átnézett, javított tételek alapján a következőképpen összegezhetjük, hogy milyen kutatási területeknek lehet hasznos forrása a kollekció: történelemtudomány, életrajz, oklevéltan, heraldika, nyelvészet, filológia, helytörténet, jogtörténet, genealógia.

Ezek közül az életrajz, heraldika, oklevéltan, történelemtudomány témakörét is érinti a két megvizsgálandó oklevél a Kaprinai-gyűjteményből.

Az első a Kaprinai B jelű rész 1. kötetének 97. kézirata (a Dedek-katalógus számozása szerint 98.) (jelzete: CollKaprB001_098_01). Ebben II. Lajos király megváltoztatja Kanizsai Dorottya címerét, aki Geréb Péter és Perényi Imre özvegye volt. (A kézirat elején levő regeszta szövege latinul: „Ludovicus II. rex Hungariae Dorotheae de Kanyza primum Petri Geréb, postea Emerici Perén viduae, arma auget." = II. Lajos Magyarország királya Kanizsai Dorottya címerét kibővíti, aki előbb Geréb Péter, majd Perényi Imre özvegye.)

Az iratot 1519-ben állították ki, a főúrnő második férje, Perényi Imre ebben az évben halt meg. A változtatás lényege, hogy Kanizsai Dorottya címerét a király kiegészíti Geréb Péter címerével „és egy új, a pajzstalpba helyezett mesteralakkal bővítette az uralkodó, olyan módon, hogy a vágott és hasított pajzs első, (heraldikai) jobb oldali mezejébe került a Geréb címer oroszlánja balra, a bal oldali mezőben található szárnyas 


\section{JEZSUITA TUDÓSOK DIGITALIZÁLT KÉZIRATGYÚJTEMÉNYEI AZ ELTE EGYETEMI KÖNYVTÁRBAN ÉS LEHETSÉGES KUTATÁSI TÉMÁIK}

sas láb felé fordulva". ${ }^{23} \mathrm{Az}$ oklevélben a király magasztalóan ír Kanizsai Dorottyáról, megemlíti, hogy mindkét férjével igen kegyesen viselkedett. Más forrásból tudjuk, hogy a művelt főúrnő a királyi udvarban is tiszteletnek örvendett. ${ }^{24}$ Kanizsai Dorottya címere kivételes abból a szempontból, hogy nő létére egyetlen közismert kivételként kapott egyedi címert. ${ }^{25}$ Érdekesség, hogy az eredeti oklevél megtalálható a Diplomatikai Levéltárban a DL 24773-as jelzet alatt, az ott levő regesztája így hangzik: „Bude - sabbato post Corp. Christi. II. Lajos király Kanysa-i Dorottyának, előbb Gereb Péter, utóbb Peren-i Imre nádorok özvegyének a Kanizsay és Geréb családok címeréből egyesített, az adománylevélben leírt és lefestett új címert adományozza. Eredeti, hártya. Függőpecsétje elveszett. Kanc. felj. - Regeszta forrása: OL regeszta (Ila)" ${ }^{26}$ A dokumentumon látszik a megváltoztatott címer is, színesen ábrázolva. A Magyar Elektronikus Könyvtárban ${ }^{27}$ megtekinthetô nagyméretű változatban. A címer részletes leírása szerepel a Pannonia regia c. kiállítási katalógusban is a IX. Késő-középkori miniatúra-festészet és reneszánsz könyvkultúra fejezetben, ${ }^{28}$ amelyben elemzik az oklevélen található kép színeit és ábráit.

Megjegyzendő, hogy az oklevélben szereplő Kanizsai Dorottya ugyanaz, aki 1526ban, a mohácsi csata után hősiesen gondoskodott a halottak eltemetéséről. Istvánffy beszámolója szerint ${ }^{29}$ saját költségén felbérelt 500 (más hivatkozás szerint $400^{30}$ ) embert a tetemek összegyűjtésére. E lépés közbiztonsági és egészségügyi szempontból is szükséges volt, mert sok kutya gyúlt a testek köré, már az arra járók biztonságát veszélyeztetve; valamint a járványveszély megakadályozása miatt (Kanizsai Dorottya ekkor még a közeli Siklós várában élt $\left.{ }^{31}\right)$.

A másik bemutatandó oklevél szintén kapcsolódik a mohácsi csatához, mivel egy kivonat, amelyben szerepel az is, hogy a véres kard körülhordozására adnak utasítást a vármegyéknek. Ez a Kaprinai-gyújtemény B jelű rész 1. kötetének 119. b) kézirata (a Dedekszámozás szerint 122., jelzete: CollKaprB001_122_01). A szöveg latin nyelvű regesztája a levél elején: „Excerptum ex quod a manuscripto coaevo, cui titulus est: 1526. Exitus pecuniarum ad facta regiae majestatis." = Kivonat egy bizonyos korabeli kéziratból, amelynek ez a címe: 1526. Kiadások a királyi őfelsége által. A király által küldött üzenetet Zophka Tamás közvetíti a vármegyéknek, a levélben szerepel, hogy „statim visis literis ipsis comes cruentatum gladium circumferri faciat" = mihelyt elolvasták a levelet, az ispánok gondoskodjanak róla, hogy körülhordozzák a véres kardot.

A statim=mihelyt szó jelzi a sürgős cselekvés szükségességét. A levél keltezése a kézirat szerint 1526. augusztus 25., tehát négy nappal a mohácsi csata előtt. A kézirat mutatja a harcra való készülést és azt, hogy a csatatéren mindenkire számítanak. A következő vármegyék ispánjai kapták Zophka Tamás apród által a levelet: Esztergom, Trencsén, Zólyom, Thurócz, Árva, Liptó, valamint ide írják az esztergomi káptalant is. Érdekes, hogy az általam keresett hazai szakirodalomban nem találtam nyomát az irat közlésének, s utalást sem találtam rá. Vagy valóban nem közölték még forrásként, vagy tüzetesebben keresve meg lehetne találni. Mindenesetre az előző oklevélhez viszonyítva ugyanazokban a forrásokban keresve nem akadtam szakirodalomra róla, a másikhoz pedig többet is találtam. 


\section{MÁTYÁs MELINDA}

\section{Összegrés}

A Hevenesi-, Kaprinai-, Pray-kéziratgyújtemény teljes egészében rendelkezésre áll digitalizált formában, amely reményeink szerint elősegíti kutatásukat. Az integrált könyvtári rendszerben a leírások pontosításával, bővítésével igyekszünk jobban kereshetővé tenni a hatalmas anyagot. A kutatási témák sokszínúsége, sokszor feltáratlan, még nem kiadott kéziratok sokasága rejlik a gyújteményben; ezekre a témákra hoztam példákat a tanulmány utolsó részében. Az ELTE Egyetemi Könyvtár örömmel veszi a kutatók visszajelzéseit a digitalizált változattal és a tételek leírásával kapcsolatban is.

\section{Irodalom}

${ }^{1}$ KNAPP Éva: A Kézirat- és Ritkaságtár tudományos ismertetője. In: Az Egyetemi Könyvtár története és gyűjteményei. Szerk. Szögi László, Budapest, ELTE Eötvös Kiadó, 2008. 205. p.

${ }^{2}$ KNAPP Éva: i. m.

${ }^{3}$ KNAPP Éva: i. m.

${ }^{4}$ Magyar múvelődéstörténeti lexikon. 4. köt. Halételek-Jordán. Főszerk. Kőszeghy Péter, Budapest, Balassi, 2005. 120. p.

${ }^{5}$ SOÓS István: Kishevesi Hevenesi Gábor (1656-1715). = Vasi honismereti és helytörténeti közlemények, 33. évf. 1. sz. 2006. 9. p.

${ }^{6}$ HEVENESI Gábor: Régi Magyar Szentség (Ungaricae Sanctitatis Indicia). Forrás: http://[-] www.ppek.hu/k59.htm [2016. január 2.]

7 SOÓS István: Kishevesi Hevenesi Gábor (1656-1715). = Vasi honismereti és helytörténeti közlemények, 33. évf. 1. sz. 2006. 10. p.

${ }^{8}$ SOÓS István: i. m. 17. p.

${ }^{9}$ Magyar művelődéstörténeti lexikon. 5. köt. Jordánszky-kódex-kolostorépítészet. Főszerk. Kőszeghy Péter, Budapest, Balassi, 2006. 91. p.

${ }^{10}$ SOÓS István: Kishevesi Hevenesi Gábor (1656-1715). = Vasi honismereti és helytörténeti közlemények, 33. évf. 1. sz. 2006. 17. p.

${ }^{11}$ Magyar múvelődéstörténeti lexikon. 5. köt. Jordánszky-kódex-kolostorépítészet. Főszerk. Kőszeghy Péter, Budapest, Balassi, 2006. 91. p.

${ }^{12}$ KÖSZEGHY Péter főszerk.: i. m.

${ }^{13}$ TÓTH András - VÉRTESY Miklós: A budapesti Egyetemi Könyvtár története (1561-1944). Budapest, Egyetemi Könyvtár, 1982. 83. p.

${ }^{14}$ SOÓS István: Kishevesi Hevenesi Gábor (1656-1715). = Vasi honismereti és helytörténeti közlemények, 33. évf. 1. sz. 2006. 18. p.

${ }^{15}$ Magyar művelődéstörténeti lexikon. 9. köt. Pálffy-rénes forint. Főszerk. Kőszeghy Péter, Budapest, Balassi, 2009. 283. p.

${ }^{16}$ BAKOS József: Az Egyetemi Könyvtár vezetői 1597-2008 között. In: Az Egyetemi Könyvtár története és gyújteményei. Szerk. Szögi László, Budapest, ELTE Eötvös Kiadó, 2008. 282. p.

${ }^{17}$ BAKOS József: i. m.

${ }^{18}$ SINKOVICS István: Pray diplomatikája. = Levéltári közlemények, 44-45. évf. 1974. 537. p.

${ }^{19}$ VARGA Klára: Digitalizálás az ELTE Egyetemi Könyvtárban. [Előadás a Valóságos könyvtár - könyvtári valóság II. c. konferencia Tudományos rétegzettség és interaktivitás - gyűj- 


\section{JEZSUITA TUDÓSOK DIGITALIZÁLT KÉZIRATGYÚJTEMÉNYEI AZ ELTE EGYETEMI KÖNYVTÁRBAN ÉS LEHETSÉGES KUTATÁSI TÉMÁIK}

teményi digitalizálás szekcióján] Forrás: https://prezi.com/pjicza6iutow/digitalizalas-az-[-] elte-egyetemi-konyvtarban [2016. január 4.]

${ }^{20}$ A Hevenesi és a Pray-gyújtemény katalógusa: Catalogus Manuscriptorum Bibliothecae Regiae Scientiarum Universitatis Budapestinensis. Tom. II. Pars 2. Catalogus litterarum originalium ac collectionis Hevenessianae et Prayanae. Budapest, 1894.; a Kaprinai-gyújteményé: Catalogus Manus criptorum Bibliothecae Regiae Scientiarum Universitatis Budapestinensis. Tom. II. Pars 3. Cat alogus collectionis Kaprinayanae. Budapest, 1907. Forrás: http://[-] konyvtar.elte.hu/hu/node/1132 [2016. január 4.]

${ }^{21}$ SZÉKELYNÉ TÖRÖK Tünde - VIRÁG Gabriella: Az Eötvös Loránd Tudományegyetem, Digitális Intézményi Tudástára: az EDIT bemutatása - két konkrét állományrész feldolgozásának ismertetésével. $=$ Tudományos és Múszaki Tájékoztatás, 62. évf. 1. sz. 2015. 9. p.

${ }^{22}$ SZÉKELYNÉ TÖRÖK Tünde - VIRÁG Gabriella: i. m.

${ }^{23}$ CSÍZI István: Magyar arisztokrata nők cimerhasználata a XVI-XVII. században. = Fons (Forráskutatás és Történeti Segédtudományok), 19. évf. 3. sz. 2012. 400. p.

${ }^{24}$ KELÉNYI Borbála: Kanizsai Dorottya végrendelete és a bajcsi pálosoknak tett adományai. = Fons (Forráskutatás és Történeti Segédtudományok), 19. évf. 4. sz. 2012. 504. p.

${ }^{25}$ CSÍZI István: i. m.

${ }^{26}$ Hungaricana: Oklevelek: Diplomatikai Levéltár (Q szekció) Kincstári levéltárból (E). MKA, Neo-regestrata acta (Q 311). 24773 Forrás: http://archives.hungaricana.hu/hu/charters[-] /288875/?query=JELZ\%3D\%2824773\%29 [2016. január 5.]

${ }^{27}$ Kanizsai Dorottya címere 1519, Buda. In: Nyulásziné Straub Éva: Öt évszázad címerei. Budapest, Corvina, 1987. 62. p. Foto: Gyarmathy László Magyar Országos Levéltár, Budapest. Forrás: http://mek.oszk.hu/01900/01918/html/index727.html [2016. január 5.]

${ }^{28}$ Pannonia regia: múvészet a Dunántúlon 1000-1541. Budapest, [Magyar Nemzeti Galéria], 1994. 476. p.

${ }^{29}$ PAPP László: A mohácsi csatahely kutatása. = Janus Pannonius Múzeum Évkönyve, 1961. 197-252. p.

${ }^{30}$ KELÉNYI Borbála: i. m. 505. p.

${ }^{31}$ PÉTER Katalin: Kanizsai Dorottya. In: Szürke eminenciások a magyar történelemben. Szerk. Szentpéteri József, Budapest, Kossuth, 2003. 47. p.

Mátyás Melinda az ELTE-n szerzett MA-diplomát informatikus könyvtáros - latin nyelv és irodalom szakpáron. 2014 szeptembere óta dolgozik az ELTE Egyetemi Könyvtárban. Fő munkaköre a Magyar Tudományos Művek Tára (MTMT) adminisztrálása, emellett a könyvár régi kéziratos anyagainak a feldolgozásával is foglalkozik. 